\title{
EL PASADO EN
}

EL PÉNDULO DE LA POLÍTICA.

ROSAS, LA PROVINCIA Y LA NACIÓN

EN EL DEBATE POLÍTICO

DE BUENOS AIRES, 1852-1861

de Alejandro Eujanian, Bernal,

Universidad Nacional de Quilmes, 2015, 308 pp.

NAHUEL PABLO VICTORERO

Universidad de Buenos Aires

El periodo que abarca desde la batalla de Caseros hasta el final de la conformación del Estado Nacional (1852-1880) ha sido analizado por la historiografía reciente. Desde el ya clásico Una Nación para el desierto argentino de Tulio Halperin Donghi a los distintos estudios, con múltiples miradas y enfoques, que han puesto en consideración un conjunto de problemáticas propias del periodo signado por el conflicto abierto entre el Estado Federal que buscaba impulsar Urquiza y el modelo de país propio de la provincia de Buenos Aires.

El libro de Eujanian es una adaptación de su tesis de doctorado y se ubica dentro de las coordenadas de esta renovación de los estudios de la década de i850. El objeto de análisis del autor consiste en el vínculo entre política y discurso histórico. Particularmente, Eujanian analiza la conformación de distintos relatos sobre el pa- sado que se gestaron a la luz de la disputa entre Buenos Aires y la Confederación urquicista. Los distintos discursos históricos en juego se desarrollaron en una creciente esfera pública y tuvieron como protagonistas a una nueva dirigencia política que buscó construir una legitimidad para conducir la organización del Estado Argentino.

Estas preocupaciones no son nuevas en la trayectoria de Alejandro Eujanian ya que es uno de los principales autores en investigar las vinculaciones entre el discurso histórico y la política. También ha analizado la profesionalización de la historia en un momento en donde la autonomía del mundo cultural se encontraba en ciernes. Este libro se sitúa en un periodo anterior al grueso de sus trabajos. Resultado de una larga investigación, el autor expone con claridad sus principales ideas estructurando el libro en tres par- 
tes que si bien dialogan entre sí abordan cuestiones analíticamente diferenciadas.

En la primera parte del libro, el autor analiza la formación de una nueva dirigencia bonaerense luego de la caída del rosismo. En este escenario, la elite política porteña encontró una alternativa plausible al integrase a la política de «olvido y fusión de partidos» que impulsaba Urquiza. Sin embargo, la evolución de los acontecimientos llevó a la ruptura de esta vía luego de la Revolución del in de septiembre de 1852 . La provincia al calor de un renacimiento de la actividad política fue protagonista de una compleja integración de exiliados políticos con ex funcionaros rosistas. Eujanian reconstruye cómo se produjo un consenso que permitió aglutinar este heterogéneo grupo político. Para el autor uno de los factores clave en esta construcción fue la vindicación de la causa porteña a partir de la oposición al proyecto y a la figura de Urquiza (asociado como la continuación de la tiranía).

En torno a la causa porteña se produjo un proceso de conformación de una identidad política que se desarrolló a través de un conjunto de operaciones. Eujanian remarca cómo un acontecimiento central la revolución del II de septiembre. El levantamiento permitió aunar a los porteńos en contra de la confederación. A la vez, a través de una política del pasado se ponderó a la ciudad como una continuadora de la tradición de Mayo y la lucha por la libertad permitiendo proyectar una visión de la provincia hacia el país. A partir de acontecimiento y sus posteriores interpretaciones, Buenos Aires pasaba a ocupar un lugar central en la lucha contra el despotismo encarnado en la figura de Urquiza. Por último, analiza en esta parte de su investigación la reconstrucción de los debates en torno a la repatriación de los restos de Rivadavia en I857. Estas operaciones permitieron elaborar a la vez una nueva forma de unanimidad en la cual se tramitó este consenso que no solo tenía la alianza entre los distintos sectores dirigentes porteños sino también que permitió proyectar a Buenos Aires como capital del país.

En la segunda parte del libro, titulada «Recordar, olvidar, encubrir: políticas del pasado en los juicios a la tiranía», el autor reconstruye y problematiza las disputas políticas en torno al pasado reciente de la provincia de Buenos Aires. Este punto resulta central, siguiendo el hilo argumental, ya que permite comprender en qué medida se logró consolidar determinados consensos al interior de una heterogénea dirigencia política frente a un pasado reciente que podía afectar los débiles lazos que la constituían. La dirigencia porteña llevó adelante un proceso de discusión de su pasado reciente lo que implicaba un desafío $\sin$ muchas certezas. Fue un momento de negociaciones y consolidación de una visión que debía posicionar a Buenos Aires como cabeza de la república. A la vez, en 
este proceso, el pueblo porteño debía poder redimirse de su apoyo a Juan Manuel de Rosas para poder construir una legitimidad en torno a la oposición a Urquiza. Para ello, Eujanian analiza tres procesos que se desarrollaron a lo largo de la década de I850: los juicios a los actos cometidos por la "mazorca» en 1854 , el proceso a Antonio Reyes (I854-I855) y el debate legislativo que antecedió al enjuiciamiento de Juan Manuel de Rosas (I856-I857).

En esta parte del libro, el autor trabajó con piezas judiciales y debates en la legislatura porteña, remarcando que estos ámbitos fueron espacios de conflictos, negociaciones, transacciones y consenso. El análisis de este tipo de documentación reviste un lugar importante dentro de la lógica del libro ya que permite explicitar «las modalidades del conflicto» en el terreno de la lucha política. Pero también en estos debates el pasado reciente fue un territorio en el que las necesidades del presente permitieron proyectar un futuro. Es decir, estas discusiones por el pasado rosista operaron sobre un presente que intentaba hacer visible un nuevo consenso. Particularmente el desarrollo de estos juicios facilitó, según Eujanian, pacificar el reclamo de los viejos exiliados del régimen ante la política de olvido impulsada por Urquiza. Por otro lado, habilitó a ex funcionarios rosistas (jueces, legisladores, oficiales del ejército y ciudadanos) a demostrar su adhesión a la causa porteña.
En la tercera parte del libro, Eujanian reconstruye los debates en torno a los "orígenes de la nación». A lo largo de dos capítulos, analiza el contexto de emergencia de la idea de una nación preexistente a I8Io durante la década de I850. El sentido de esta idea está asociado al interés de las elites porteñas de anexar los orígenes de la nación a la reciente causa porteña. A través de una prolija reconstrucción de los debates legislativos, el autor afirma que en I852 fue Vicente Fidel López el primero en sostener la preexistencia de la nación para impugnar el acuerdo de San Nicolás. Posteriormente, será Bartolomé Mitre quien repondrá esta argumentación en los debates de I854 en el contexto de la elaboración de la constitución bonaerense. Es importante remarcar que, durante los debates, el fundamento utilizado para justificar la preexistencia de la Nación se dio a través de una noción pactista. Eujanian analiza finalmente las distintas elaboraciones de la célebre Historia de Belgrano y sus contextos. A la vez, considera la obra Historia Argentina de Luis Domínguez, en la cual Mitre encontró coordenadas para entablar la discusión.

El libro de Eujanian contribuye a ampliar los aportes y lecturas que la historiografía reciente ha puesto como ejes centrales sobre la década de 1850 . Por un lado, brinda una visión compleja de los conflictos políticos abiertos con la secesión de Buenos Aires analizando las dis- 
tintas alternativas en pugna en el proceso. la prensa, procesos judiciales y moviliPor el otro, permite abrir la interpretación zaciones fueron el escenario en donde el sobre el nacimiento y características prin- discurso histórico sobre el pasado reciente cipales de la tradición política porteña. El se fue configurando. El resultado de este trabajo está fundamentado en un sólido proceso permitió un conjunto de imágetrabajo documental: imágenes, memo- nes sobre el rosismo que posteriormente rias, folletos, prensa, debates judiciales y fueron revisitadas por el llamado «protolegislativos. El lector se encontrará con revisionismo histórico». Eujanian expliciun heterogéneo corpus de fuentes que es ta, pues, cómo las motivaciones políticas atravesado por las problemáticas sugeri- fueron construyendo mediante omisiones das por el autor y sus sugerentes hipótesis. y negociaciones el conjunto de discursos Uno de los puntos centrales que la obra históricos que circulaban a lo largo de la brinda al lector es la complejidad del de- década de 1850. En un contexto previo a bate público y la centralidad del pesado la formación de un campo propiamente en un proceso de fuerte disputa política. histórico, el trabajo permite dar luz a las Debates parlamentarios, discusiones en formas de hacer y pensar la historia. 